\title{
EFEKTIVITAS PENGELOLAAN ALOKASI DANA DESA DI DESA SAMBANGAN KABUPATEN BULELENG
}

\author{
Dinda Agustin, Komang Febriantyi, Putu Ade Indrawan, \\ Ni Putu Rikasari Santi \\ Jurusan Akuntansi, Universitas Pendidikan Ganesha, Singaraja, Bali, Indonesia
}

\begin{abstract}
Abstrak
Penelitian ini bertujuan tingkat efektivitas pengelolaan alokasi dana desa, Apa saja hambatan yang dihadapi dalam merealisasikan alokasi dana desa dan cara menanggulangi hambatan dalam merealisasikan alokasi dana desa. Dalam penelitian ini menggunakan metode kualitatif. Penelitian kualitatif merupakan penelitian yang digunakan untuk menghasilkan data deskriptif yang ditulis atau yang diucapkan orang dan perilaku - perilaku yang dapat diamati. Dalam penelitian ini menggunakan dua teknik pengumpulan data, yakni wawancara, dan observasi. Dalam hal ini peneliti melakukan wawancara kepada Sekretaris Desa Sambangan dan penelitian ini melakukan observasi ke narasumber untuk bertatap muka dalam melakukan wawancara dan melihat langsung Kantor Perbekel Desa Sambangan. tingkat efektifitas pengelolaan alokasi dana di Desa Sambangan yaitu sudah lebih efektif dari sebelumnya. Dikarenakan anggaran sudah dikelola oleh desa itu. Saat ini alokasi dana desa yang sudah langsung di bawah kendali desa itu sendiri lebih cepat dalam merealisasi kesejahteraan Desa Sambangan karena memiliki ruang yang lebiih besar untuk mengakomodir aspirasi masyarakat.
\end{abstract}

Kata kunci: Dana Desa, Efektivitas, Realisasi

\begin{abstract}
This study aims at the effectiveness of the management of the allocation of village funds, What are the obstacles faced in realizing the allocation of village funds and how to overcome obstacles in realizing the allocation of village funds. In this study using qualitative methods. Qualitative research is research that is used to produce descriptive data that is written or spoken by people and observable behaviors. In this study using two data collection techniques, namely interviews, and observation. In this case the researcher conducted an interview with the Secretary of the Village of Sambangan and this study conducted observations to the interviewees to meet face to face in conducting interviews and see first hand the Village Office of the Sambangan Village. the level of effectiveness in managing the allocation of funds in Sambangan Village is already more effective than before. Because the budget has been managed by the village. At present the allocation of village funds that are directly under the control of the village itself is faster in realizing the welfare of Sambangan Village because it has more space to accommodate the aspirations of the community.
\end{abstract}

Keywords : Village Funds, Effectiveness, Realization

\section{Pendahuluan}

Pendahuluanmemuattentanglatarbelakang, landasanteori, masalah, Saat ini pemerintah mengubah sistem penyelenggaraan pemerintah daerah dari sistem sentralisasi menjadi sistem desentralisasi membuat desa bebas untuk mengurus rumah tangganya sendiri. Dalam Undang-Undang No 32 Tahun 2004 pasal 1 ayat 5, otonomi daerah adalah hak, wewenang, dan kewajiban daerah otonom untuk mengatur dan mengurus sendiri urusan pemerintah dan kepentingan masyarakat setempat sesuai dengan peraturan perundang-undangan. Pemberian otonomi daerah berarti memberikan kewenangan dan keleluasaan kepada daerah untuk mengelola dan memanfaatkan sumber daya daerah secara efektif, agar tidak terjadi penyimpangan dan penyelewengan, serta harus diikuti dengan pengawasan yang kuat. Otonomi desa dituntut memberikan pelayanan yang lebih efektif sehingga masyarakat ikut terlibat dalam program kegiatan pembangunan agar terlaksananya program kegiatan pembangunan desa dengan baik guna memajukan daerah agar tercapainya peningkatan kesejahteraan masyarakat desa. 
Dengan adanyanya perubahan tersebut masing-masing daerah bisa berbenah dan mengambil kebijakan sistem pemerintahannya sesuai dengan kondisi budaya dan masyarakat didesa tersebut Dikeluarkannya Undang-undang Nomor 6 Tahun 2014 tentang Desa memberikan perubahan daerah dan pemerintahan lebih baik dari aspek kewenangan, perencanaan, pembangunan, keuangan dan demokrasi desa.

Peraturan Menteri Dalam Negeri Nomor 113 Tahun 2014 menyebutkan bahwa pengelolaan keuangan desa adalah keseluruhan kegiatan yang meliputi perencanaan, pelaksanaan, penatausahaan, pelaporan, dan pertanggungjawaban keuangan desa. Pengelolaan keuangan desa merupakan rangkaian siklus yang terpadu dan terintegrasi antara satu tahapan dengan tahapan lainnya.

Dalam Peraturan Menteri Dalam Negeri Nomor 13 Tahun 2006 tentang Pedoman Pengelolaan Keuangan Daerah, dikatakan transparan adalah prinsip keterbukaan yang memungkinkan masyarakat untuk mengetahui dan mendapatkan akses informasi seluasluasnya tentang keuangan daerah.

Dalam Peraturan Menteri Dalam Negeri Nomor 37 Tahun 2007 tentang Pedoman Pengelolaan Keuangan Desa, partisipasi memakai kata-kata partisipatif, yaitu keikutsertaan dan keterlibatan masyarakat secara aktif dalam proses pembangunan karena partisipasi masyarakat merupakan bagian yang tidak terpisahkan dari pembangunan itu sendiri, sehingga nantinya seluruh lapisan masyarakat akan memperoleh hak dan kekuatan yang sama untuk menuntut atau mendapatkan bagian yang adil dari manfaat pembangunan tersebut.

Di Kabupaten Buleleng pemerintah daerah mengalokasikan dana ke tiap-tiap desa sebesar $20 \%$ atau Rp 20 miliar. Dana yang di alokasikan digunakan untuk pembangunan berbagai proyek di masing-masing desa. Selain itu, alokasi dana tersebut agar dimanfaatkan untuk program-program padat karya untuk membuka lapangan pekerjaan bagi masyarkat desa setempat guna meminimalisisr angka pengangguran dan jumlah warga miskin.

Dengan adanya perubahan tersebut, dulunya desa hanya diberikan dana yang terbatas untuk melaksanakan pembangunan dan pengelolaannya yang sangat minim oleh satuan instansi pemerintahan yang ada diatasnya, akan tetapi setelah kebijakan alokasi dana desa yang sekarang, alokasi anggaran yang cukup besar dan pengelolaannya dilakukan secara mandiri, sehingga banyak keraguan terhadap kemampuan desa untuk mengelola alokasi dana tersebut. Maka dari itu pada penelitian kali ini mengangkat topik pembahasan tentang "Efektifitas Pengelolaan Alokasi Dana Desa (ADD)". Menurut Mardiasmo (2004), Efektivitas adalah ukuran berhasil tidaknya suatu organisasi mencapai tujuannya. Apabila suatu organisasi berhasil mencapai tujuan, maka organisasi tersebut dikatakan telah berjalan dengan efektif. Efektivitas adalah mengukur hubungan antara hasil pungutan suatu pajak dengan target penerimaan pajak itu sendiri.

Menurut Nurcholis (2011:88-89) Alokasi Dana Desa adalah penyaluran dana melalui kas Desa yang diperoleh dari APBD Kabupaten/Kota yang bersumber dari bagian dana perimbangan keuangan pusat dan daerah yang diterima oleh Kabupaten/Kota untuk Desa paling sedikit 10\% (sepuluh persen). Menurut Peraturan Menteri Dalam Negeri Nomor 113 Tahun 2014 tentang Pedoman Pengelolaan Keuangan Desa, Alokasi Dana Desa, selanjutnya disingkat ADD, adalah dana perimbangan yang diterima kabupaten/kota dalam Anggaran Pendapatan dan Belanja Daerah kabupaten/kota setelah dikurangi Dana Alokasi Khusus.

Berdasarkan permasalahan diatas, adapun rumusan masalah yang dilakukan yaitu Bagaimana tingkat efektivitas pengelolaan alokasi dana desa, Apa saja hambatan yang dihadapi dalam merealisasikan alokasi dana desa, Bagaimana cara menanggulangi hambatan dalam merealisasikan alokasi dana desa.

\section{Metode \\ Desain Penelitian}

Dalam penelitian ini menggunakan metode kualitatif. Penelitian kualitatif merupakan penelitian yang digunakan untuk menghasilkan data deskriptif yang ditulis atau yang diucapkan orang dan perilaku - perilaku yang dapat diamati. 


\section{Lokasi Penelitian}

Lokasi penelitian ini adalah Kantor Perbekel Desa Sambangan, Kecamatan Sukasada, Kabupaten Buleleng.

\section{Objek dan Subjek Penelitian}

Objek dalam penelitian ini mengambil data Efektifitas pengelolaan alokasi dana Desa Sambangan. Subjek dalam penelitian ini adalah pihak internal Kantor Perbekel Desa Sambangan.

\section{Sumber Data}

Dalam penelitian ini sumber data yakni Sekretaris Desa Sambangan.

\section{Teknik Pengumpulan Data}

Dalam penelitian ini menggunakan dua teknik pengumpulan data, yakni wawancara, dan observasi.

1. Metode Wawancara yang digunakan dalam penelitian ini wawancara terstruktur, yang mana peneliti sudah mempersiapkan pertanyaan - pertanyaan yang akan dijawab oleh narasumber atau informan. Dalam hal ini peneliti melakukan wawancara kepada Sekretaris Desa Sambangan

2. Observasi merupakan bagian dalam pengumpulan data yang langsung dari lapangan, yang mana dalam penelitian ini melakukan observasi ke narasumber untuk bertatap muka dalam melakukan wawancara dan melihat langsung Kantor Perbekel Desa Sambangan.

\section{Hasil dan Pembahasan}

\section{Tingkat Efektifitas Pengelolaan Alokasi Dana}

Desa sangat penting bagi kesejahteraan desa itu sendiri karena pengelolaan alokasi dana termasuk hal penting untuk menjalankan serta merealisasikan apa yang seharusnya di butuhkan pada desa. Dimana menurut Indriyo, Prinsip Anggaran dan Pembelanjaan Perusahaan, (1997:27) mengatakan bahwa dana adalah merupakan kekayaan atau aktiva yang diperlukan untuk melakukan kegiatan sehari-hari dan selalu berputar.

Bambang Riyanto, Dasar-Dasar Pembelanjaan Perusahaan (2004 : 49) mengemukakan bahwa dana dengan adanya tiga konsep yaitu :

1. Konsep Kwantitatif

Konsep ini mendasarkan pada kwantitas dari pada dana yang tertanam dalam keseluruhan unsur-unsur aktiva lancar dimana aktiva ini merupakan aktiva yang sekali berputar kembali dalam bentuk semula, atau aktiva dimana dana tertanam di dalamnya akan dapat bebas lagi dalam waktu yang pendek. Dana yang dimaksud adalah modal kerja bruto, yaitu keseluruhan dari pada aktiva lancar.

2. Konsep Kwalitatif

Konsep ini adalah sebagian dari aktiva lancar yang benar-benar dapat digunakan untuk membiayai operasi perusahaan tanpa mengganggu likuiditasinya.Dana yang dimaksud adalah modal kerja netto yaitu yang merupakan kelebihan aktiva lancar di atas hutang lancarnya.

3. Konsep Fungsional

Konsep ini berdasarkan fungsi dari pada dana dalam menghasilkan pendapatan (income). Setiap dana yang dikerjakan dalam perusahaan adalah dimaksud untuk menghasilkan laba.

Dari peneletian yang kita lakukan di Kantor Desa Sambangan Kabupaten Buleleng yakni dengan Bapak Murtia sekretaris desa di Desa Sambangan bahwa tingkat efektifitas pengelolaan alokasi dana di Desa Sambangan yaitu sudah lebih efektif dari sebelumnya. Dikarenakan anggaran sudah dikelola oleh desa itu sendiri. Sebelumnya yaitu dana anggaran desa masih di tangan pemerintah pusat jadi untuk merealisasikan suatu keluhan dari desa itu sendiri membutuhkan waktu yang lama untuk di proses dari waktu pengajuan yang sudah diajukan kantor desa ke pemerintah pusat. Saat ini alokasi dana desa yang sudah langsung di bawah kendali desa itu sendiri lebih cepat dalam merealisasi kesejahteraan Desa Sambangan karena memiliki ruang yang lebiih besar untuk 
mengakomodir aspirasi masyarakat. Contohnya untuk perbaikan jalan bisa bertahun-tahun untuk menunggu pemerintah pusat. Sedangkan sekarang sudah lebih cepat meskipun tergantung dana yang kita dapatkan. Dengan pengelolaan sendiri ini pendapatan dari pariwisata di Desa Sambangan lebih mudah memantau.

\section{Hambatan Yang Dihadapi Dalam Merealisasikan Alokasi Dana Desa}

Dalam mengelola alokasi dana hingga mewujudkan perbaikan-perbaikan dari keluhan warga pastinya ada hambatan dibalik semua itu. Untuk secara teknis di lapangan tidak ada hambatan karena semua sudah disiapkan tentang perencana, pelaksana, dan sebagainya.

Hambatannya dari pengalokasian dana desa yakni adanya perubahan regulasi dari pemerintah, perubahan waktu karena seperti pada tahun 2017 ada padat karya tunai jadi harus mengubah RAB yang harus di ajukan. Badan pengawas yang mengawasi yakni di Desa Sambangan ada BPD. Dimana Regulasi adalah berbagai peraturan atau persyaratanpersyaratan jika berada disuatu institut,Tujuan regulasi yakni untuk mengendalikan masyarakat dalam suatu lembaga-lembaga yang berada didalamnya dengan batasanbatasan yang telah ditentukan.

\section{Cara Menanggulangi Hambatan Dalam Merealisasikan Alokasi Dana Desa}

Untuk mencapai suatu tujuan, tidak tertutup kemungkinan kita akan menghadapi berbagai hambatan atau kesulitan, yang berasal dari eksternal maupun internal. Dalam hal ini pihak pengelola alokasi dana yaitu Kantor Perbekel Desa Sambangan mengatakan bahwa dalam hal menanggulangi hambatan yang terjadi dengan sering-sering berkomunikasi dengan pemerintah provinsi terkait regulasi yang terjadi.

\section{Simpulan dan Saran Simpulan}

Dari peneletian yang kami lakukan maka disimpulkan bahwa tingkat efektifitas pengelolaan alokasi dana di Desa Sambangan yaitu sudah lebih efektif dari sebelumnya. Dikarenakan anggaran sudah dikelola oleh desa itu. Saat ini alokasi dana desa yang sudah langsung di bawah kendali desa itu sendiri lebih cepat dalam merealisasi kesejahteraan Desa Sambangan karena memiliki ruang yang lebiih besar untuk mengakomodir aspirasi masyarakat.

\section{Saran}

Saran buat Kantor Perbekel Desa Sambangan yaitu lebih sering melakukan komunikasi terkait dengan regulasi yg terjadi guna meningkatkan efektivitas pengelolaan dana desa didesa yg bersangkutan. Dan diharapkan dapat transparansi , akuntabilitas, dan tetap menerapkan standar akuntansi yang berlaku.

\section{DAFTARPUSTAKA}

Budianas, Nanang. 2013. Teori Ilmu Manajemen dan Akuntansi "Pengertian Dana”. Diakses Melalui $\quad$ https://ilmumanajemendanakuntansi.blogspot.com/2013/02/pengertiandana.html?M=1 Pada 5 Januari 2019

Julianto, adi.2017.Efektivitas Pengelolaan alokasi Dana Desa (ADD) Di Kecamatan Sembakung Kabupaten Nunukan. Journal Pemerintahan Integratif . 5 (4): 478487.ejournal.pin.or.id

Nurcholis, Hanif. 2011. Pertumbuhan dan Penyelenggaraan Pemerintahan Desa. Jakarta: Erlangga.

Peraturan Menteri Dalam Negeri Nomor 13 Tahun 2006 tentang Pedoman Pengelolaan Keuangan Daerah

Peraturan Menteri Dalam Negeri Nomor 37 Tahun 2007 tentang Pedoman Pengelolaan Keuangan Desa,

Peraturan Menteri dalam Negeri Nomor 113 Tahun 2014 Tentang Pengelolaan Keuangan Desa 
Peraturan Pemerintah Nomor 43 tahun 2014 tentang Desa

Rahum, Abu. 2015. Pengelolaan Alokasi Dana Desa (Add) Dalam Pembangunan Fisik Desa Krayan Makmur Kecamatan Long Ikis Kabupaten Paser. eJournal IImu Pemerintahan, 2015 : 3 (4) 1623-1636.

Sulastri, Nova. 2016. Efektivitas Pengelolaan Alokasi Dana Desa (Add) Dalam Meningkatkan Pembangunan Fisik Desa Lakapodo Kecamatan Watopute Kabupaten Muna.

Undang-Undang Nomor 32 tahun 2004 tentang pemerintah daerah

Undang Undang Nomor 32 Tahun 2004 Tentang Pemerintahan Daerah

Undang-Undang Republik Indonesia Nomor 6 tahun 2014 